\title{
Selection and heritability of F2 sweet pepper offspring from the cross Amfora $\times$ Piquillo de Lodosa
}

\author{
Dario Danojević* · Slađana Medić-Pap · Janko Červenski
}

Institute of Field and Vegetable Crops, Maksima Gorkog 30, 21000 Novi Sad, Serbia

\begin{abstract}
Summary: Peppers (Capsicum annuum L.) have a very diverse use in Serbia. Preparing ajvar (pepper spread) is the most common way in Serbia to preserve pepper for wintertime. Besides larger fruits, high total soluble solids in red pepper fruits are very important for better ajvar. The goal of our breeding program is to develop new pepper cultivars with high fruit weight and high total soluble solids. For this purpose, we crossed Amfora (kapia variety from the Institute of Field and Vegetable Crops, Novi Sad, Serbia) and Piquillo de Lodosa (a small conical variety from Spain) in 2014. From this crossing, $180 \mathrm{~F} 2$ plants were transplanted into open field in 2016. The fruits were evaluated for seven quantitative traits: weight, length, diameter, index, locule number, pericarp thickness and total soluble solids (Brix). The principal component analysis was used to identify the most significant traits. The mean values were compared with the Dunnett test. Relationships between traits were calculated by Pearson correlation coefficients. Fruits from F2 plants were ranged between parents mainly. Fruit weight was positively correlated with fruit length, fruit diameter and pericarp thickness, but negatively with total soluble solids. Low heritability for total soluble solids and a negative correlation between total soluble solids and fruit weight makes it difficult to improve both important traits in one variety. The task in the future breeding process is to find crossing combination in pepper which will harmonize these two important fruit traits.
\end{abstract}

Key words: sweet pepper, fruit, breeding, ajvar

\section{Introduction}

Pepper genus (Capsicum sp.) is one of the most important vegetables and spice crops all over the world. Historians believe that pepper had been used as a human nutrition between 7200 and 5200 B.C. in South America (MacNeish, 1964). Pepper (Capsicum annum L.) is also one of the major vegetable crops in Serbia. Comparing to other vegetable species (apart from potato), in term of production area, pepper has the first rank in Serbia with 16,977 ha in 2016 (Statistical Office of the Republic of Serbia, 2017). Consumers in different parts of Serbia prefer pepper fruits of various shapes, sizes and colours and it has a great range of use in Serbia (Danojević et al., 2016). Besides the fresh consumption, pepper is usually used as roasted, stuffed (with various fillings), pickled, dried, ground, and processed in many different ways (Danojević et al., 2017a). Preparing ajvar (pepper spread)

Corresponding author:

dario.danojevic@ifvcns.ns.ac.rs

Acknowledgment:

This study was funded by the Ministry of Education, Science and Technological Development of the Republic of Serbia, under the project TR 31030. Also are grateful to Jaime Prohens and Adrian Rodriguez-Burruezo from Spain for providing the seed of Piquillo de Lodosa. is the most common way to preserve pepper fruits for a winter time especially in Southern Serbia. Commonly, kapia pepper type is used for ajvar. Besides larger fruits, high dry matter content or high total soluble solids in red pepper fruits are very important traits for better ajvar.

Fruit characteristics are the most influential variables in grouping peppers (Occhiuto et al., 2014). Studying 67 morphological and physiological traits with Principal Component Analysis, Bozokalfa et al. (2009) found that the greatest variation in the first two principal components was prescribed to fruit traits. Smith and Basavaraj (2006) and Bharadwaj et al. (2007) noted that during pepper selection very important traits were: fruit weight, fruit length, and fruit diameter. Those traits directly affect the fruit yield per plant. Choosing some important fruit traits and using Principal Component Analysis or Cluster Analysis is an appropriate method for visual presentation of pepper varieties phenotypic variation (Danojević et al., 2017b). It is very important that desirable plant traits have high heritability, especially if heritability is over $80 \%$, selection for that trait should fairly be easy (Singh, 1990). According to Rêgo et al. (2011) total soluble solids (TSS) was positively correlated with fruit dry matter content. Therefore TSS can be used in the breeding process to improve dry matter content. One of the main breeding goals in the Institute of Field and Vegetable Crops in Novi 
Sad is to produce a pepper variety with large fruits and high total soluble solids for preparing ajvar.

\section{Materials and Methods}

Varieties Amfora (kapia variety, registered 2001 year, from the Institute of Field and Vegetable Crops, Novi Sad, Serbia), and Piquillo de Lodosa (a small conical variety from Spain) were crossed in 2014 (Figure 1 and 2, respectively).

Variety Piquillo de Lodosa was used as famous in Spain, because of its full taste, rich aroma and high total soluble solids (Eggink et al., 2012). In the following year 2015, F1 generation was produced in order to get F2 seed. In 2016, seed was sown on 31 March in a plastic house, and plants were transplanted on 7 June into open field. The field trial was conducted at the experimental field of the Institute of Field and Vegetable Crops (Rimski Šančevi), Novi Sad (Serbia) in two augmented blocks, with 180 non-common treatments (F2 plants) and 2 common treatments, which were varieties of Amfora and Piquillo de Lodosa. For data analysis, each plant was considered as a replicate of the non-common treatments, and in the case of common checks, 10 plants per block were used. The distance between plants in the row was $25 \mathrm{~cm}$ and between rows $70 \mathrm{~cm}$. Regular cultural practices were applied throughout the growing season (inter-row cultivation, irrigation, treatment against bacterial leaf spot and insect pests). Eighteen F2 plants were randomly chosen and covered with agro

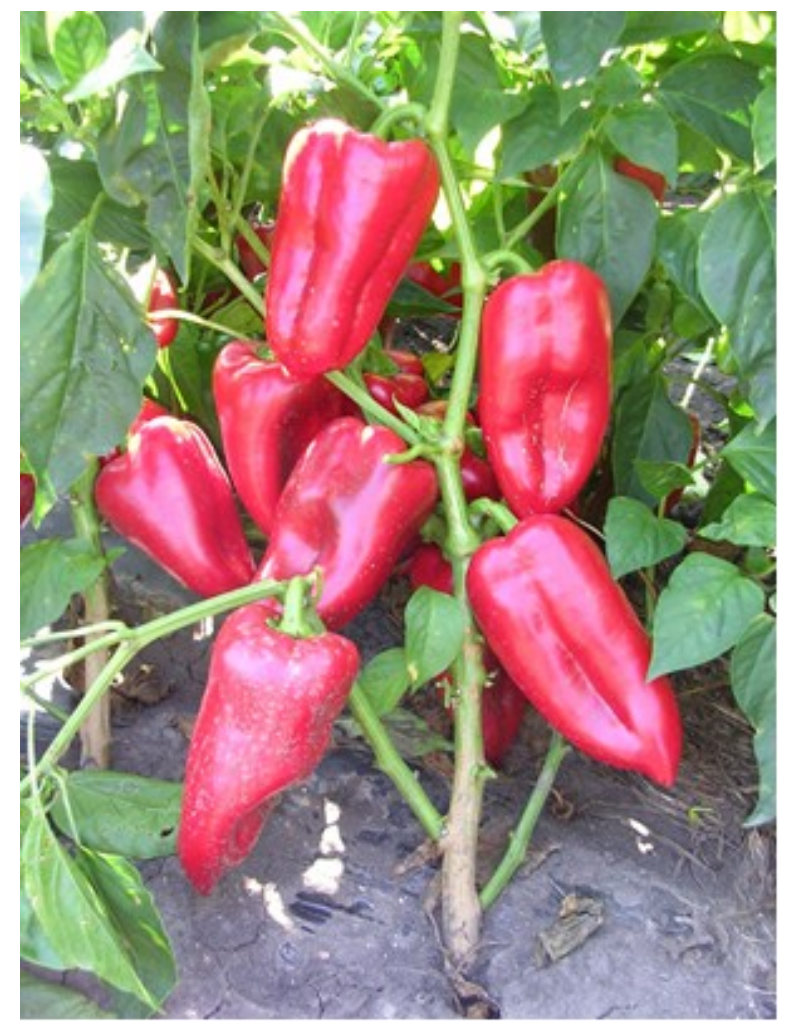

Figure 1. Mother plant (Amfora) textile isolators. All fruits from isolated plants were harvested in physiological maturity in October and used for a fruit evaluation. The sample of 174 fruits was analysed for seven quantitative traits: Fruit Weight (g) [FW], Fruit Length $(\mathrm{cm})[\mathrm{FL}]$, Fruit Diameter $(\mathrm{cm})$ [FD], Fruit Index - Fruit Length/Diameter [F], Locule Number [LN], Pericarp Thickness (mm) [PT], and Total Soluble Solids ( ${ }^{\circ}$ Brix) [TSS]. The principal component analysis (PCA) was used to identify the most significant traits. Common components coefficients, eigenvalues, and relative and cumulative proportions of the total variance expressed by single traits were calculated. The first two components explaining the maximum variance were selected for the ordination analysis, and the correlation between the original traits and the respective principal component was calculated. Traits with correlation above 0.6 were considered relevant for that component (Matus et al., 1999). The mean values were compared with the Dunnett test at 0.05 and 0.01 probability level. Relationships between all traits were calculated by Pearson correlation coefficients. Statistical data processing was done in Software package Statistica ver. 12 for PCA. The broad sense heritability was estimated according to the formula of Mahmud and Kramer (1951):

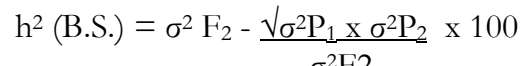

Where,

$\mathrm{h}^{2}$ (B.S) $=$ broad sense heritability. $\sigma^{2} \mathrm{~F}_{2}=$ variance of $\mathrm{F}_{2}$ generation. $\sigma^{2} \mathrm{P}_{1}=$ variance of parent 1 . $\sigma^{2} \mathrm{P}_{2}=$ variance of parent 2 .

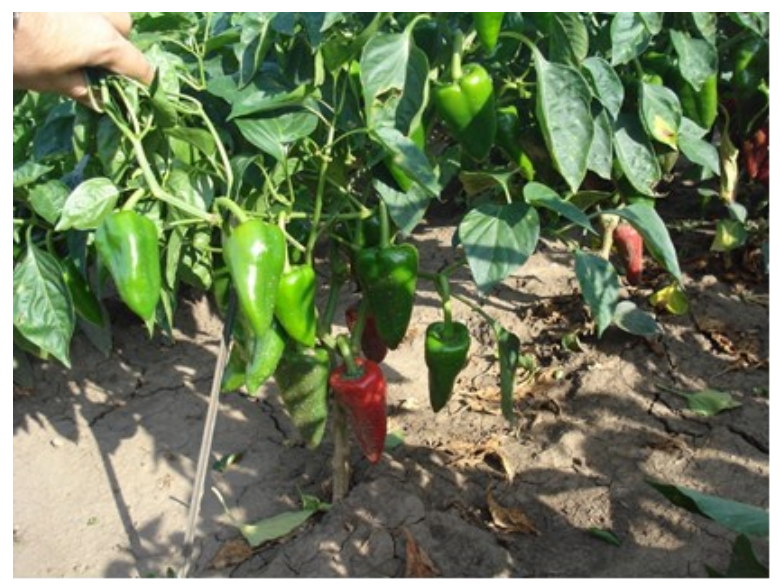

Figure 2. Father plant (Piquillo de Lodosa)

\section{Results and Discussion}

The principal component analysis revealed that TSS had a positive influence on the first principal component (PC1), while FW, FD and PT had significant, but negative influence (Table 1). The first PC was $47.819 \%$ of total variability. FL and FI had the 
most important and negative correlation in PC2, with variance $30.246 \%$. The $\mathrm{LN}$ had the highest influence in PC 3, but that PC had only $15.756 \%$ of total variance. Because of that, LN was excluded from further analysis.

Traits FW, PT and FD are close to each other on biplot, which indicates positive correlations between them (Figure 3). TSS was on the opposite side which indicates a negative correlation with FD, PT and FW. The lowest influence on the first two PC had LN.

Based on tested characteristics in PCA, fruits from F2 genotypes were distributed between parents (Amfora and Piquillo de Lodosa) (Figure 4 and 5). Fruits from genotype No. 5 and 15 tended to be more like Amfora (wider and heavier fruits), while fruits from genotypes 7,10 and 13 had a higher Brix like Piquillo de Lodosa. The most distinguished fruits had genotype 17 because of the highest FI and FL.

Amfora had higher FW, FL, FD and PT than Piquillo de Lodosa, but lower TSS (Table 2). According to threeyear study, Gvozdenović et al. (2002) reported that Amfora had an average FW of 116 g, FL $12.1 \mathrm{~cm}$, FD 5.6 $\mathrm{cm}$ and PT $4.8 \mathrm{~mm}$. These results are lower than those obtained in our research. The Piquillo de Lodosa variety in our trial had average FW $41.6 \mathrm{~g}$, FL $9.3 \mathrm{~cm}$, FD $4.7 \mathrm{~cm}$. This variety has Protected Denomination of Origin in
Table 1. Factor coordinates of the variables, based on correlations, Eigenvalues and variance in first significant Principal Component (PC)

\begin{tabular}{cccc}
\hline Trait & PC 1 & PC 2 & PC 3 \\
\hline FW & $\mathbf{- 0 . 9 5 9}$ & -0.182 & 0.136 \\
FL & -0.118 & $\mathbf{- 0 . 9 6 2}$ & 0.185 \\
FD & $\mathbf{- 0 . 8 9 1}$ & 0.333 & 0.236 \\
FI & 0.426 & $\mathbf{- 0 . 8 8 9}$ & -0.087 \\
LN & -0.180 & 0.012 & $\mathbf{- 0 . 9 7 4}$ \\
PT & $\mathbf{- 0 . 9 2 2}$ & -0.014 & -0.153 \\
TSS & $\mathbf{0 . 7 4 3}$ & 0.505 & 0.113 \\
\hline $\begin{array}{c}\text { Eigenvalue } \\
\text { \% Total variance }\end{array}$ & 3.347 & 2.117 & 1.103 \\
Cumulative variance \% & 47.819 & 30.246 & 15.756 \\
\hline
\end{tabular}

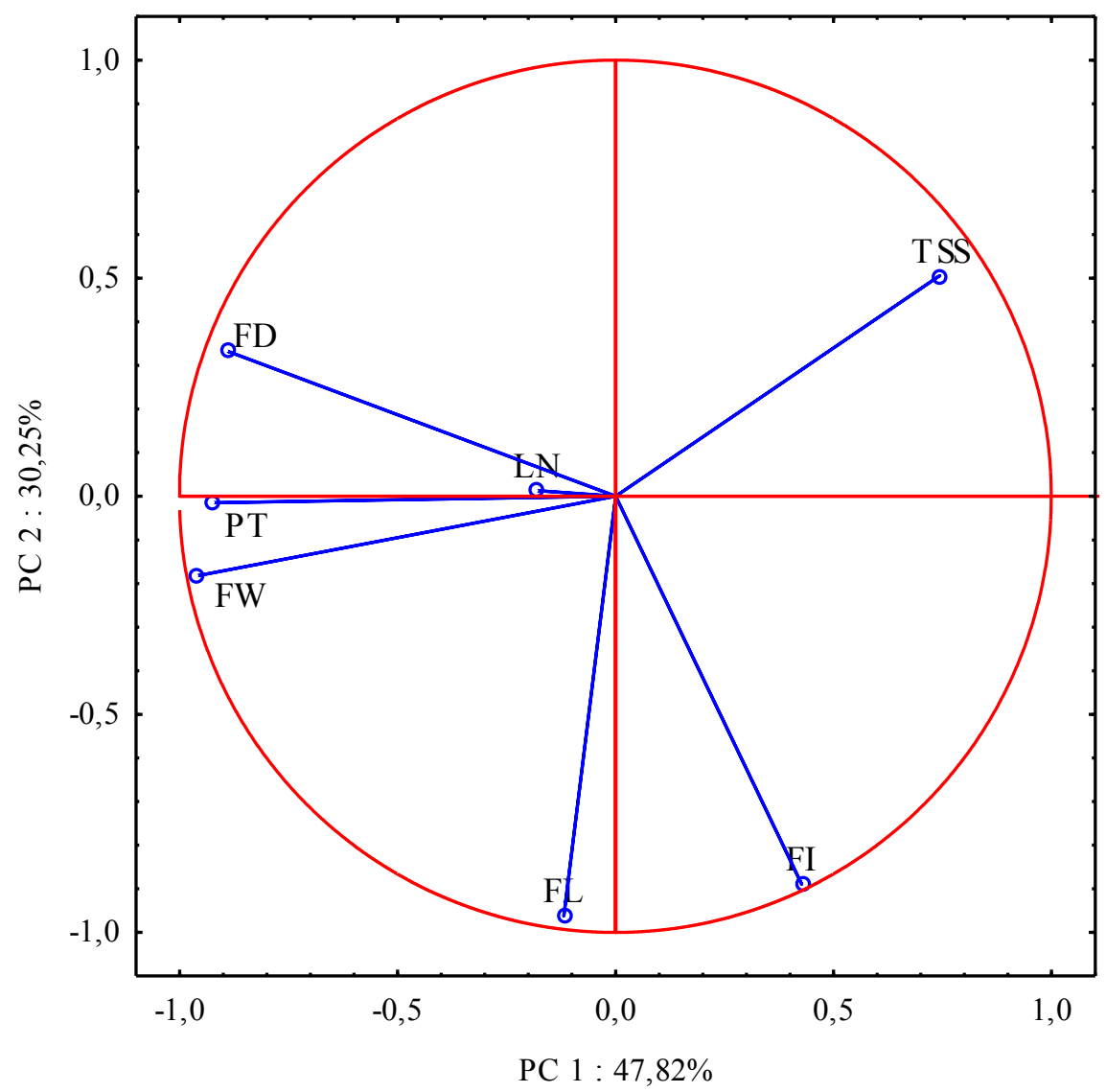

Figure 3. Projection of evaluated traits based on first two Principal Component 


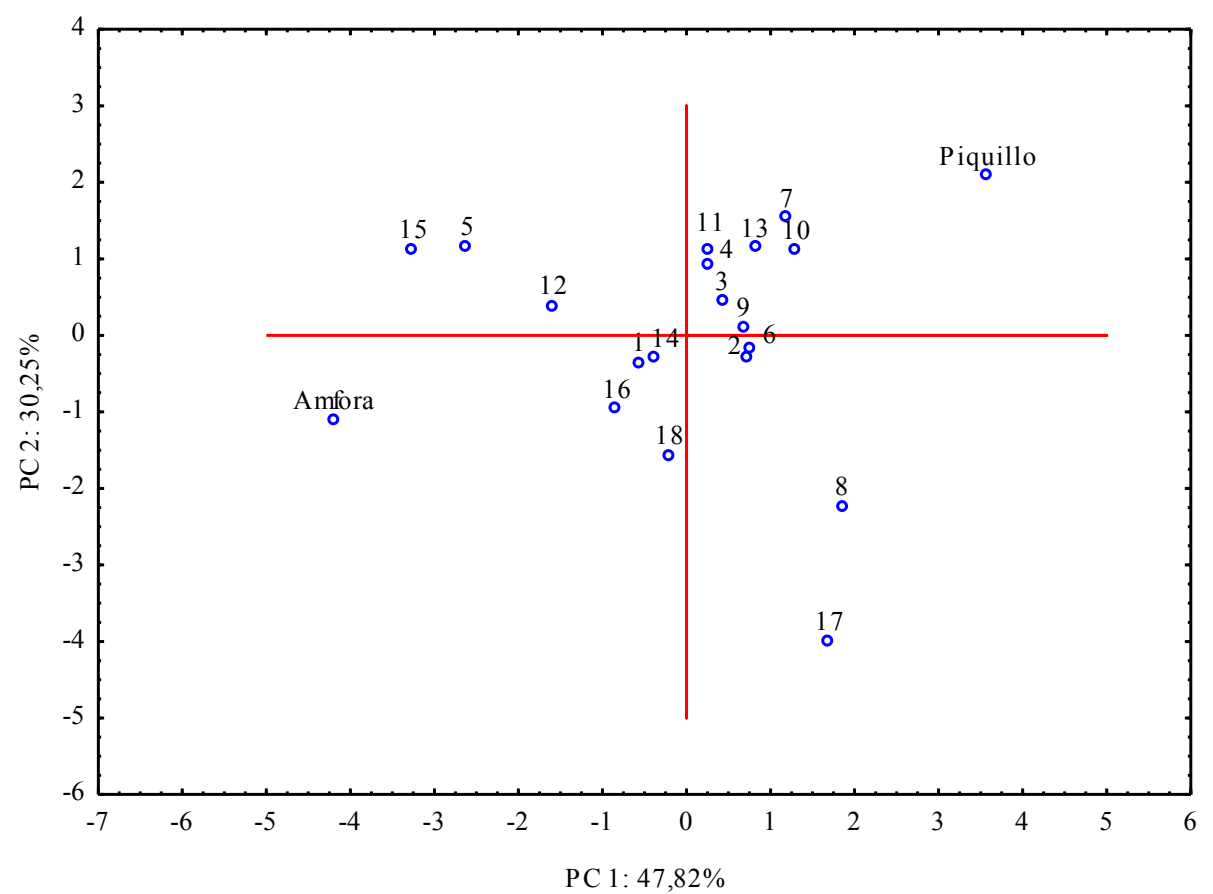

Figure 4. Biplot of evaluated pepper genotypes according to the first two Principal Component

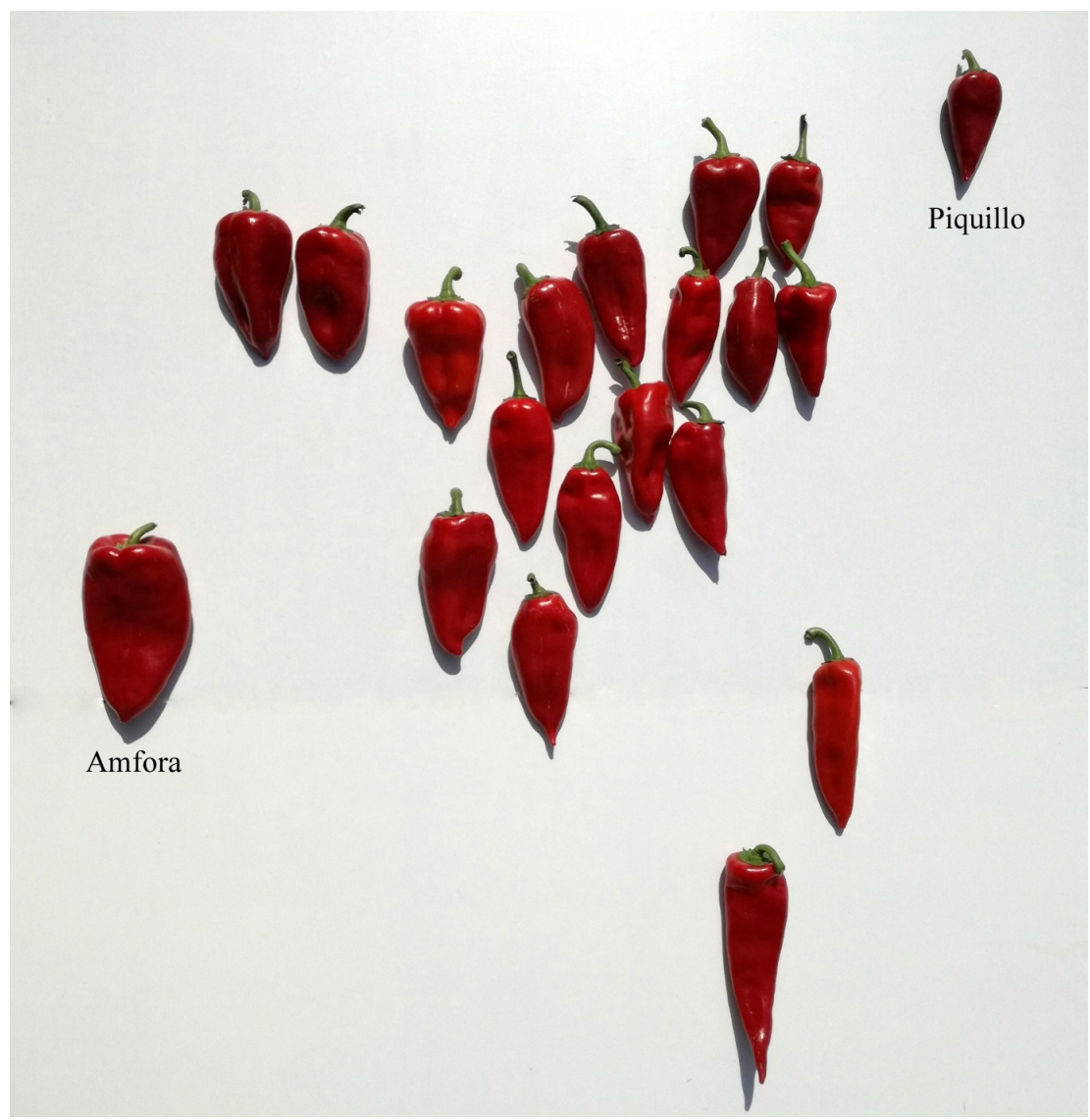

Figure 5. Amfora, Piquillo de Lodosa and their F2 progenies represented with typical fruits arranged according to Principal Component Analysis 
Table 2. Mean values and heritability of analysed pepper fruit traits

\begin{tabular}{|c|c|c|c|c|c|c|}
\hline $\begin{array}{c}\text { Genotype No./ } \\
\text { Variety }\end{array}$ & $\begin{array}{c}\mathrm{FW} \\
(\mathrm{g})\end{array}$ & $\begin{array}{l}\mathrm{FL} \\
(\mathrm{cm})\end{array}$ & $\begin{array}{l}\text { FD } \\
(\mathrm{cm})\end{array}$ & FI & $\begin{array}{l}\text { PT } \\
(\mathrm{mm})\end{array}$ & $\begin{array}{c}\text { TSS } \\
\left({ }^{\circ} \text { Brix }\right)\end{array}$ \\
\hline 1 & $93.80 \mathrm{pp}$ & $12.79 \mathrm{pp}$ & $5.81 \mathrm{pp}$ & 2.24 & $3.96 \mathrm{pp}$ & 7.25 \\
\hline 2 & $68.36 \mathrm{pp}$ & $11.80 \mathrm{pp}$ & 5.09 & 2.36 & $3.61 \mathrm{p}$ & 7.08 \\
\hline 3 & $69.09 \mathrm{pp}$ & 10.91 & 5.20 & 2.12 & $3.97 \mathrm{pp}$ & 7.34 \\
\hline 4 & $78.70 \mathrm{pp}$ & 10.38 & 5.48 & 1.91 & 3.54 & 7.44 \\
\hline 5 & $105.80 \mathrm{pp}$ & 10.52 & $6.70 \mathrm{pp}$ & 1.59 & $5.00 \mathrm{pp}$ & 6.97 \\
\hline 6 & $73.78 \mathrm{pp}$ & $11.82 \mathrm{pp}$ & 4.87 & $2.46^{\mathrm{a}} \mathrm{pp}$ & $3.92 \mathrm{pp}$ & $7.69^{\text {aa }}$ \\
\hline 7 & 66.08 & 10.30 & 5.50 & 1.88 & 3.60 & $8.43^{\text {aa }}$ \\
\hline 8 & $61.81 \mathrm{p}$ & $14.17 \mathrm{pp}$ & 4.30 & $3.36^{\mathrm{aa}} \mathrm{pp}$ & $3.31 \mathrm{p}$ & $7.26^{\mathrm{a}}$ \\
\hline 9 & $63.29 \mathrm{p}$ & 10.56 & 4.63 & 2.30 & $3.90 \mathrm{pp}$ & 7.01 \\
\hline 10 & 58.11 & 10.30 & 5.14 & 2.02 & $3.54 \mathrm{p}$ & $7.96^{\text {aa }}$ \\
\hline 11 & $72.72 \mathrm{pp}$ & 10.09 & 5.36 & 1.91 & $3.81 \mathrm{pp}$ & $7.56^{\mathrm{az}}$ \\
\hline 12 & $96.86 \mathrm{pp}$ & $11.81 \mathrm{pp}$ & $6.30 \mathrm{pp}$ & 1.89 & $4.23 \mathrm{pp}$ & 7.04 \\
\hline 13 & $68.87 \mathrm{p}$ & 10.65 & 5.58 & 1.92 & $3.60 \mathrm{p}$ & $7.95^{\text {aa }}$ \\
\hline 14 & 88.33 pp & $11.87 \mathrm{p}$ & 5.20 & 2.30 & $4.23 \mathrm{pp}$ & 7.10 \\
\hline 15 & $112.93 \mathrm{pp}$ & 10.02 & $6.65 \mathrm{pp}$ & 1.52 & $5.03 \mathrm{pp}$ & 6.45 \\
\hline 16 & $94.45 \mathrm{pp}$ & $13.05 \mathrm{pp}$ & $5.85 \mathrm{pp}$ & 2.24 & 3.50 & 6.15 \\
\hline 17 & $73.80 \mathrm{pp}$ & $16.43^{\mathrm{a}} \mathrm{pp}$ & 4.03 & $4.11^{\mathrm{aa}} \mathrm{pp}$ & $3.65 \mathrm{p}$ & 7.19 \\
\hline 18 & $87.29 \mathrm{pp}$ & $14.03 \mathrm{pp}$ & 5.46 & $2.61^{\mathrm{aa}} \mathrm{pp}$ & $3.57 \mathrm{p}$ & 6.54 \\
\hline Amfora & $145.07 \mathrm{pp}$ & $14.52 \mathrm{pp}$ & $7.18 \mathrm{pp}$ & 2.03 & $5.27 \mathrm{pp}$ & 6.34 \\
\hline $\begin{array}{l}\text { Piquillo de } \\
\text { Lodosa }\end{array}$ & 41.60 & 9.34 & 4.75 & 1.98 & 2.47 & $9.18^{\text {az }}$ \\
\hline $\mathrm{h}^{2}(\%)$ & 79.75 & 83.99 & 77.56 & 90.69 & 59.59 & 43.78 \\
\hline
\end{tabular}

${ }^{\text {a }}{ }^{\text {aa }}$ significantly higher at 0.05 and 0.01 probability level than Amfora of the Dunnett test, respectively

p, pp significantly higher at 0.05 and 0.01 probability level than Piquillo de Lodosa of the Dunnett test, respectively

Spain, and according to Ministerio de Agricultura, Pesca y alimentación (n.d.) it ought to have FW 25-50 g, up to $10 \mathrm{~cm} \mathrm{FL}$ and, 4-5 cm FD, which is corresponding to the measurements in this experiment. Eggink et al. (2012) noted that the variety Piquillo de Lodosa, in the Netherlands, had TSS $10.37^{\circ}$ Brix, which is more than in our research. However, these plants were grown in a greenhouse.

The FW in F2 generation ranged from $61.8-112.9 \mathrm{~g}$ (Table 2). The progeny mean values were between parental average values in FW (lower than Amfora, and higher than Piquillo de Lodosa). Sixteen from eighteen F2 genotypes had higher FW than Piquillo de Lodosa. FL in F2 generation ranged from $10.0 \mathrm{~cm}$ (genotype No. 15) to $16.4 \mathrm{~cm}$ (genotype No. 17). Only fruits of genotype No. 17 were longer than Amfora $(14.5 \mathrm{~cm})$. The fruits of F2 genotypes were also between parents for FD and PT. The higher FI than Amfora had genotypes No. 6, 8, 17 and 18.

Six genotypes $(6,7,8,10,11$ and 13$)$ had higher TSS than Amfora, but lower than Piquillo de Lodosa. According to Stevanović (1986), the dry matter content of hybrids was in most cases between parental values. This claim is presented in our research, for the TSS, too. According to Geleta et al. (2004), TSS of hybrids in red fruits were lower than in parents with no statistically significant differences, while TSS in green fruits was significantly lower compared to parents. Additionally, these authors stated that the value of heterosis for this trait was negative in all combinations. In this study, the

Table 3. Pearson's coefficient of correlation between fruit traits in parents and F2 pepper progeny Amfora $\times$ Piquillo de Lodosa

\begin{tabular}{ccccc}
\hline Trait & FL & FD & PT & TSS \\
\hline FW & $0.34^{* *}$ & $0.84^{* *}$ & $0.71^{* *}$ & $-0.56^{* *}$ \\
FL & & 0.09 & $0.20^{* *}$ & $-0.36^{* *}$ \\
FD & & & $0.60^{* *}$ & $-0.46^{* *}$ \\
PT & & & & $-0.42^{* *}$ \\
\hline
\end{tabular}

** significant at 0.01 probability level 
highest heritability was recorded for FI and lowest was noted for TSS (90.7\% and $43.8 \%$, respectively). Similar results for heritability of FW $63.8 \%$, and FL $78.4 \%$ was obtained in hot pepper (C. annum) (Marame et al. 2009). Crossing between a bell pepper and small chili, narrow sense heritability for TSS was low (0.24-0.54\%) (Ben Chaim and Paran, 2000).

According to the results, most of the traits exhibited heritability value within the range of $78-91 \%$. This means that the genetic variation dominated environmental variance and that the inheritance for these traits vastly relies on major gene system. Consequently, the offspring phenotypic variation follows parental variation more closely, and the breeder is in position to make a better presumption about the phenotypic variation of the progeny, following the parental variation. While PT and TSS phenotypic variation is almost half to half dependent on genotypic and environmental variance, directing to the conclusion that minor gene system plays a more significant role in the inheritance of these two traits, making a task of breeding harder.

Among the fruit traits, statistically significant correlations were noted. FW was positively correlated with FL, FD and PT (Table 3). TSS had negative correlations with all evaluated fruit traits. Zečević (2001) found that FD, FL, PT, number of fruits and FW are in a strong positive correlation. In the previous research the positive correlation of FW, FD and PT to TSS was noted, probably because of different breeding material and the fact that those fruits were harvested at technological maturity (Danojević et al. 2016).

\section{Conclusions}

A desirable variability that could be selected for further breeding in fruit weight was found within F2 progeny Amfora $\times$ Piquillo de Lodosa. Quite high correlations were obtained between fruit diameter and fruit weight, which means that these two traits are each other's phenotypic marker. Therefore, the high value of fruit diameter could be a good indicator of the high value of fruit weight, and vice versa. Low heritability for total soluble solids and a negative correlation between total soluble solids and fruit weight makes difficult to improve both important traits in future variety from this crossing. The task in the future breeding process is to find crossing combination in pepper which will harmonize these two important fruit traits.

\section{References}

Ben-Chaim, A., Paran I. (2000). Genetic analysis of quantitative traits in pepper (Capsicum annuum L.). Journal of the American Society Horticultural Science, 125: 66-70.

Bharadwaj, D. N., Singh, H., Yadav, R. K. (2007). Genetic variability and association of component characters for yield in chilli (Capsicum annum L.). Progressive Agriculture, 7(1-2), 72-74.
Bozokalfa, M. K., Esiyok, D., Turhan, K. (2009). Patterns of phenotypic variation in a germplasm collection of pepper (Capsicum annuum $\mathrm{L}$.) from Turkey. Spanish Journal of Agriculture Research, 7, 83-95.

Danojević, D., Medić-Pap, S., Savić, A., Červenski, J. (2016). Fruit Traits of Pepper Genotypes Originating from Open Pollination. Ratarstvo $i$ Pourtarstvo, 53 (2), 69-73. doi:10.5937/ratpov53-9761

Danojević, D., Medić-Pap, S., Franeta, F., Ignjatov, M., Takač, A., Cervenski, J. (2017a). Značajni momenti u proizvodnji paprike. Zbornik referata 51. Savetovanje agronoma i poljoprivrednika Srbije (SAPS), Zlatibor, 22-28. Januar 2017. Institut za ratarstvo i povrtarstvo, Novi Sad, 62-70.

Danojević, D., Medić-Pap, S., Červenski, J. (2017b). NS pepper varieties in a multivariate fruit analysis. Proceedings of the VIII International Scientific Agriculture Symposium “AGROSYM 2017', 5th - 8th of October 2017, Jahorina mountain, Bosnia and Herzegovina, 495500. http://www.agrosym.rs.ba/agrosym/agrosym_2017/ BOOK_OF_PROCEEDINGS_2017_FINAL.pdf

Eggink, P. M., Maliepaard, C., Tikunov, Y., Haanstra, J. P. W., Bovy, A.G., Visser, R. G. F. (2012). A taste of sweet pepper: Volatile and non-volatile chemical composition of fresh sweet pepper (Capsicum annum) in relation to sensory evaluation of taste. Food Chemistry 132, 301-310. doi.org/10.1016/j.foodchem.2011.10.081

Geleta, L. F., Labuschagne, M. T., Viljoen, C. D. (2004). Relationship between heterosis and genetic distance based on morphological traits and AFLP markers in pepper. Plant Breeding 123, 467-473.

Gvozdenović, Đ., Bugarski, D., Takač, A., Červenski, J. (2002). Amfora a new pepper cultivar. Zbornik radova Instituta za ratarstvo $i$ pourtarstvo, Novi Sad, 36, 69-73.

MacNeish, R. S. (1964). Ancient Mesoamerican civilization. Science, 143, 531-537.

Mahmud, I., Kramer, H. H. (1951). Segregation of yield, height and maturity following soybean crosses. Agronomy Journal, 43, 605609.

Marame, F., Dessalegne, L., Fininsa, C., Sigvald R. (2009). Heterosis and heritability in crosses among Asian and Ethiopian parents of hot pepper genotypes. Euphytica, 168, 235-247. doi:10.1007/ s10681-009-9912-9.

Matus, I., Gonzales, M. I., Del Pozo A. (1999). Evaluation of phenotypic variation in a Chilean collection of garlic (Allium sativum L.) clones using multivariate analysis. Plant Genetic Resources Newsletter, 117:31-36.

Ministerio de agricultura, pesca y alimentación (n.d.). Denominación de origen Pimiento del Piquillo de Lodosa. Retrieved from http://www.mapama.gob.es/es/alimentacion/temas/calidadagroalimentaria/registro_INDO_tcm7-206219.pdf

Occhiuto, P. N., Peralta, I. E., Asprelli, P. D., Galmarini, C. R. (2014). Characterization of Capsicum Germplasm Collected in Northwestern Argentina Based on Morphological and Quality Traits. AgriScientia, 31, 63-73.

Rêgo, E. R., Rêgo, M. M., Finger, F. L., Cruz, C. D., Casali, V. W. D. (2011). Phenotypic diversity, correlation and importance of variables for fruit quality and yield traits in Brazilian peppers (Capsicum baccatum). Genetic Resources and Crop Evolution, 58, 909918. doi:10.1007/s10722-010-9628-7

Singh B. D. (1990). Plant breeding, principles and methods. Kalyani Publishers, New Delhi, 376.

Smitha, R. P., Basavaraja, N. (2006). Variability and correlation studies in chilli (Capsicum annum L.). Karnataka Journal of Agricultural Sciences, 19 (4), 888-891.

Statistical Office of the Republic of Serbia (2017). Database. RZS, Belgrade, Retrieved from http://webrzs.stat.gov.rs/WebSite/ public/ReportView.aspx.

Stevanović, D. (1986). The inheritance of fruit traits in diallel reciprocal hybrids of different types of pepper (Capsicum annum L.). Doctoral dissertation (in Serbian). University of Belgrade, Faculty of Agriculture.

Zečević, B. (2001). Influence of parental germplasma on quantitative traits of pepper (Capsicum annuum L.) F1, F2 and F3 generation. Doctoral dissertation (in Serbian). University of Belgrade, Faculty of Agriculture. 


\section{Selekcija i heritabilnost F2 potomstva paprike iz ukrštanja Amfora $\times$ Piquillo de Lodosa}

\section{Dario Danojević · Slađana Medić-Pap · Janko Červenski}

Sažetak: Paprika (Capsicum annum L.) u Srbiji ima veoma raznovrsnu upotrebu. Čest način čuvanja paprike za zimski period je u vidu ajvara. Osim krupnih plodova koji imaju debeo perikarp, za kvalitetan ajvar takođe je bitan visok sadržaj suve materije. Cilj našeg rada je da dobijemo oplemenjivački materijal sa visokim sadržajem suve materije, odnosno rastvorljive suve materije i krupnih plodova. Za ovu svrhu smo 2014. godine ukrstili Amforu (sorta Instituta za ratarstvo i povrtarstvo, Novi Sad, Srbija) i Piquillo de Lodosa (sorta paprike konusnog ploda iz Španije). Sledeće 2015. godine proizvedena je F1 generacija u cilju dobijanja semena F2 generacije. U 2016. godini rasađeno je 180 F2 biljaka. Roditeljske biljke (Amfora i Piquillo de Lodosa) su korištene kao kontrola. Slučajno je odabrano 18 F2 biljaka koje su pokrivene izolatorima od agro tekstila. Plodovi su ubrani u fiziološkoj zrelosti (oktobar) i korišćeni su za dalju analizu. Izmerena su sledeća kvantitativna svojstva: masa ploda $(\mathrm{g})$, dužina ploda $(\mathrm{cm})$, prečnik ploda $(\mathrm{cm})$, broj komora, debljina perikarpa $(\mathrm{mm})$ i ukupno rastvorljiva suva materija ( ${ }^{\circ}$ Brix). Indeks ploda je obračunat kao odnos dužine i širine. Analiza glavnih komponenti (PCA) je korišćena za identifikaciju najznačajnijih svojstava. Srednje vrednosti su upoređene Danetovim testom. Prema PCA, rastvorljiva suva materija je imala pozitivan uticaj na prvu glavnu komponentu (PC1), dok su masa ploda, širina ploda i debljina perikarpa imale značaj, ali negativan uticaj. Dužina i indeks ploda imali su najvažniji i negativan uticaj na PC2. Plodovi F2 generacije bili su uglavnom između roditelja (Amfora i Piquillo de Lodosa). Masa plodova je u pozitivnoj korelaciji sa dužinom i širinom ploda, kao i sa debljinom perikarpa, ali u negativnoj sa ukupno rastvorljivom suvom materijom. Niska heritabilnost rastvorljive suve materije i negativna korelacija sa masom ploda otežava povećanje ova dva bitna svojstva u jednoj sorti. Zadatak u budućem oplemenjivačkom radu na paprici je da se pronađu roditelji koji će pomiriti ova dva važna svojstva.

Ključne reči: slatka paprika, plod, oplemenjivanje, ajvar 